\title{
How images make world politics: International icons and the case of Abu Ghraib
}

\author{
LENE HANSEN*
}

\begin{abstract}
This article introduces international icons to the field of International Relations. International icons are freestanding images that are widely circulated, recognised, and emotionally responded to. International icons come in the form of foreign policy icons familiar to a specific domestic audience, regional icons, and global icons. Icons do not speak foreign policy in and of themselves rather their meaning is constituted in discourse. Images rise to the status of international icons in part through images that appropriate the icon itself, either in full or through inserting parts of the icon into new images. Appropriations might be used and read as critical interventions into foreign policy debates, but such readings should themselves be subjected to analysis. A three-tier analytical and methodological framework for studying international icons is presented and applied in a case study of the hooded prisoner widely claimed to be emblematic of the Abu Ghraib prison scandal.
\end{abstract}

Lene Hansen is Professor of International Relations in the Department of Political Science, University of Copenhagen. She is author of Security as Practice: Discourse Analysis and the Bosnian War (Routledge, 2006) and co-author (with Barry Buzan) of The Evolution of International Security Studies (Cambridge University Press, 2009).

\section{Introduction}

It is now a decade since the photos from the prison in Abu Ghraib were shown, first to an American audience watching Sixty Minutes II on 28 April 2004, then almost instantaneously reaching anyone with a television or internet connection. The photographs documented abuse that the US media had already been informed was under investigation, but which in the absence of images had generated little

\footnotetext{
* Earlier versions of this article have been presented at seminars in the Department of Political Science, University of Copenhagen, and at the International Studies Association's Annual Conference in San Francisco, 3-6 April 2013 and in Toronto, 26-9 March 2014. I wish to thank discussants and audiences on those occasions for questions, criticism, and suggestions. I am particularly grateful to the following for their detailed feedback: the four anonymous reviewers, the editors of the Review of International Studies, Jacob Alsted, Rebecca Adler-Nissen, Henrik Breitenbauch, Barry Buzan, Peter Marcus Kristensen, Henrik Larsen, Debbie Lisle, Megan MacKenzie, Mette Mortensen, Iver B. Neumann, Karen Lund Petersen, Lisa Richey, Laura Shepherd, Ole Wæver, Cynthia Weber, and Michael C. Williams; and to Simone Molin Friis and Johan Spanner for comments and research assistance. Research for this article was carried out as part of the project on 'Images and International Security' funded by the Danish Council for Independent Research - Social Sciences, Grant number DFF 1327-00056B.
} 
coverage. ${ }^{1}$ The sense of horror and disbelief within America was immediate and widespread and in spite of President George W. Bush's attempt to explain that 'This is not America', ${ }^{2}$ the photos 'have become symbols in the Arab world of American imperialism'. ${ }^{3}$ As one military official put it, this was a 'moral Chernobyl'. ${ }^{4}$ Chock and outrage was generated by the brutality of the abuse, the vast number of photos, and the multiple forms of violence depicted. ${ }^{5}$ Yet, as often happens when multiple images represent the same event, some quickly gained a heightened circulation: the female guard Lynndie England with a collapsed prisoner on a leash, pyramids of naked prisoners with smiling guards posing behind them, prisoners facing barking dogs, and scenes of forced masturbation. As 'Abu Ghraib' became part of what Cornelia Brink calls collective visual memory, one photo stood out as 'the most emblematic': the one showing a hooded prisoner on a cardboard box, clad in a poncho-like blanket, arms outstretched and wires attached, who was told that electrocution would appear were his arms to fall down. ${ }^{6}$ The image, now known as 'The Hooded Man', was on the cover of the 8 May issue of The Economist beneath the headline 'Resign, Rumsfeld', the opening photo of Seymour Hersh's much quoted essay on 10 May in The New Yorker and in many other media reports. ${ }^{7}$ Over the coming months and years, the hooded prisoner - and other photos from Abu Ghraib - moved from the news media to museum spaces, exhibition catalogues, and academic publications. "The Hooded Man"s rise to iconic status has been produced not just by its frequent reproduction, but by the numerous ways in which it has been appropriated by image makers across a variety of genre, media, and locations. It has been the template for magazine covers and editorial cartoons, on murals, public posters, sculpture, recreated in Lego, and inserted into paintings and montages. ${ }^{9}$

Assessing the political impact of 'Abu Ghraib' in general and the hooded prisoner in particular is not easy. Those sceptical of its effect argue that US mainstream news media largely followed the Bush Administration's framing of Abu Ghraib as 'abuse',

1 The New York Times ran a short story on 21 March 2004, which briefly noted that six soldiers had been charged by the American military 'in connection with alleged abuse of prisoners in Iraq' and that eleven others were suspended due to ongoing investigations. Thon Shanker, 'The Struggle for Iraq: The Military; 6 G. I.'s in Iraq Are Charged With Abuse of Prisoners', New York York Times, 21 March 2004.

2 George W. Bush, 'Interview With Alhurra Television, May 5, 2004', Public Papers of the Presidents of the United States: George W. Bush (2004, Book I) (Washington, DC: Government Printing Office), pp. 767-70, 768

3 David D. Perlmutter, 'Photojournalism and Foreign Affairs', Orbis, 49:1 (2005), pp. 109-22, 121.

4 Quoted in Dora Apel, 'Torture Culture: Lynching Photographs and the Images of Abu Ghraib', Art Journal, 64:2 (2005), pp. 88-100, 100

5 Conclusive evidence as to how many images were circulated to the media is hard to find, but on 12 May 2004 members of the US Congress are reported to have been shown 'over eighteen hundred photographs and video'. Apel, 'Torture Culture', p. 98.

6 Cornelia Brink, 'Secular Icons: Looking at Photographs from Nazi Concentration Camps', History \& Memory, 12:1 (2000), pp. 135-50; Apel, 'Torture Culture', p. 91.

7 Seymor Hersh's article was posted on-line on 30 April 2004, while the printed version appeared in The New Yorker on 10 May. Seymore M. Hersh, 'Torture at Abu Ghraib', The New Yorker, 80:11 (2004), pp. $42-7$.

8 See, for example, 'Inconvenient Evidence: Iraqi Prison Photographs from Abu Ghraib', International Center of Photography, New York, 17 September-28 November 2004; and Stephen F. Eisenman, The Abu Ghraib Effect (London: Reaktion Books, 2007).

9 See Apel, 'Torture Culture'; Eisenman, The Abu Ghraib Effect; Kari Andén-Papodopoulos, 'The Abu Ghraib Torture Photographs: News Frames, Visual Culture, and the Power of Images', Journalism, 9:5 (2008), pp. 5-30; Eamonn Carrabine, 'Images of Torture: Culture, Politics and Power', Crime, Media, Culture, 7:1 (2011), pp. 5-30; W. J. T. Mitchell, Cloning Terror: The War on Images, 9/11 to the Present (Chicago: The University of Chicago Press, 2011); and Neil McWilliam (ed.), Lines of Attack: Conflicts in Caricature (Durham, NC: Duke University, 2010) for images of some of these appropriations. 
not 'torture', ${ }^{10}$ that the photos did not prevent George W. Bush's re-election in 2004, that prosecution and convictions have been few and targeted lower level personnel, ${ }^{11}$ and that the wider American use of detention and confinement in the War on Terror continued. ${ }^{12}$ Yet, while no direct, immediate causal impact on American policy can be established, the hooded prisoner and the violations he embodies continue to resurface in critiques of America's role in the world, at home and abroad. In 2009, one example of American leaders continuing to take 'Abu Ghraib' seriously was evidenced by President Barack Obama's blocking of the release of up to 2,000 new photographs of alleged prisoner abuse on the grounds that they would 'inflame antiAmerican public opinion and [to] put our troops in greater danger'. ${ }^{13}$

'The Hooded Man' is far from the only example of an iconic image's ability to represent key events in international politics. A Western-centric list from World War II onwards includes the raising of the flag at Iwo Jima (1945), the shooting of a suspected Vietcong in Saigon during the Tet Offensive (1968), the naked girl fleeing the napalm bombing in Vietnam (1972), the Bosnian prisoners behind barbed wire (1992), the falling World Trade Center Towers on 11 September (2001), the toppling of Saddam Hussein's statue (2003), the charred, lynched contractors from Fallujah (2004), and the dying Iranian activist Neda Agha Soltan (2009). ${ }^{14}$ As the last example indicates, icons can originate from civilians present at the scene with nothing but cell phones. The Muhammad Cartoon Crisis of 2006 shows that iconic - and highly contested - images can come from a variety of genres, including nondocumentary ones like cartooning. Iconic images do more than transmit 'what happens'. They condense and constitute the meaning of major events like World War II, Vietnam, and the War on Terror. They are, as David D. Perlmutter puts it, believed to 'say it all', not least as time moves on and 'lessons' crystallise. ${ }^{15}$ To make an analogy to discourse analysis, icons can be seen in Ernesto Laclau and Chantal Mouffe's term as 'visual nodal points': privileged discursive/visual signs that provide a partial fixation to structures of meaning. ${ }^{16}$ Yet as the nodal point relies on linking and differentiation to other signs for meaning to be generated, the icon does not 'speak' foreign policy on its own. It is drawn upon by discursive agents to constitute events, threats, subjects, and identities, to defend policies taken or promote alternatives not pursued. Icons are on the one hand presented as if they have a self-evident foreign policy

10 W. Lance Bennett, Regina G. Lawrence, and Steven Livingston, 'None Dare Call It Torture: Indexing and the Limits of Press Independence in the Abu Ghraib Scandal', Journal of Communication, 56:3 (2006), pp. 467-85. For a critique of the methodology and the negative conclusions of Bennett et al., see Douglas V. Porpora, Alexander Nikolaev, and Julia Hagemann, 'Abuse, Torture, Frames, and the Washington Post', Journal of Communication, 60:2 (2010), pp. 254-70.

11 Eisenman, The Abu Ghraib Effect, pp. 7-8.

12 Laleh Khalili, Time in the Shadows: Confinement in Counterinsurgencies (Stanford: Stanford University Press, 2013).

13 Quoted in Alex Spillius, 'Barack Obama Attempts to Block Torture Photos', The Telegraph (14 May 2009).

14 Perlmutter, 'Photojournalism'; Robert Hariman and John Louis Lucaites, No Caption Needed: Iconic Photographs, Public Culture, and Liberal Democracy (Chicago: Chicago University Press, 2007); David Campbell, 'Atrocity, Memory, Photography: Imaging the Concentration Camps of Bosnia - the Case of ITN Versus Living Marxism, Part 1', Journal of Human Rights, 1:1 (2002), pp. 1-33; Mette Mortensen, 'When Citizen Photojournalism Sets the News Agenda: Neda Agda Soltan as a Web 2.0 Icon of PostElection Unrest in Iran', Global Media and Communication, 7:1 (2011), pp. 4-16.

15 David D. Perlmutter, Photojournalism and Foreign Policy: Icons of Outrage in International Crisis (Westport, Connecticut: Praeger, 1998), p. 17.

16 Ernesto Laclau and Chantal Mouffe, Hegemony \& Socialist Strategy: Towards a Radical Democratic Politics (London: Verso, 1985), p. 112. 
message, yet on the other hand, we frequently find competing constructions of what that 'self-evident' message is.

Over the past fifteen years, scholars from the fields of Political Communication, Sociology, Art History, English Language and Literature, and Visual Culture have produced a substantial body of work on how to define and analyse the icon. ${ }^{17}$ Yet icons have not been explicitly theorised within International Relations (IR) nor have they been subjected to empirical studies. ${ }^{18}$ This article seeks to fill this gap. The starting point is that while many scholars within IR might be sympathetic to the argument that iconic images are important to world politics there is not a clear understanding of what that 'importance' is or how to study it. The goal of the article is thus two-fold: to provide a set of concepts and distinctions that allow us to identify a phenomenon - international icons - and to develop a theoretical framework through which one can analyse the ways in which icons impact world politics.

These goals place the article as a contribution to current research within the field of IR on images and international politics. Scholars like David Campbell and Michael C. Williams called a decade ago for IR to meet 'the pictorial challenges' and acknowledge the specificity of the 'communicative acts' that images perform, and a substantial body of work has risen to the occasion. ${ }^{19}$ A distinctive concern in parts of that work has been whether a critical potential can be attributed to - or drawn from - images. Cynthia Weber, for example, has shown how in some cases 'contemporary popular visual language might more successfully evacuate political responsibility from politics than textual language now can', while other studies have focused on images that may identify resistance in 'previously unacknowledged political spaces' and conjure different ways of being critical than those familiar from spoken or written texts. ${ }^{20}$ Starting from securitisation theory, Frank Möller and Juha Vuori have discussed the conditions under which images may desecuritise, that is, facilitate a move out of the logic of urgency, threats, and radical measures that characterise

17 Some of the key monographs and edited volumes are Perlmutter, Photojournalism and Foreign Policy; Hariman and Lucaites, No Caption; Mitchell, Cloning Terror; and Jeffrey C. Alexander, Dominik Bartmanski, and Bernhard Giesen (eds), Iconic Power: Materiality and Meaning in Social Life (New York: Palgrave Macmillan, 2012).

18 Axel Heck and Gabi Schlag set out an iconological approach, yet their focus is on images in general, rather than the specificity of the (international) icon. Heck and Schlag, 'Securitizing Images: The Female Body and the War in Afghanistan', European Journal of International Relations, 19:4 (2013), pp. 891-913.

19 David Campbell, 'Cultural Governance and Pictorial Resistance: Reflections on the Imaging of War', Review of International Studies, 29:Special Issue (2003), pp. 57-73, 57; Michael C. Williams, 'Words, Images, Enemies: Securitization and International Politics', International Studies Quarterly, 47:4 (2006), pp. 511-31, 527. For responses to Williams's call see Frank Möller, 'Photographic Interventions in Post-9/11 Security Policy', Security Dialogue, 38:2 (2007), pp. 179-96; Juha Vuori, 'A Timely Prophet? The Doomsday Clock as a Visualization of Securitization Moves with a Global Referent Object', Security Dialogue, 41:3 (2010), pp. 255-77. The concern with visual representation has been a part of poststructuralism since the late 1980s, most noticeable in the work of Michael J. Shapiro and James Der Derian, but poststructuralists did not formulate an explicit research agenda like the one that has crystallised over the past decade. Michael J. Shapiro, The Politics of Representation: Writing Practices in Biography, Photography, and Policy Analysis (Madison, WI: The University of Wisconsin Press, 1988); James Der Derian, Antidiplomacy: Spies, Terror, Speed, and War (Oxford: Basil Blackwell, 1992).

20 Cynthia Weber, 'Popular Visual Language as Global Communication: The Remediation of United Airlines Flight 93', Review of International Studies, 34:Special Issue (2008), pp. 137-53, 153; Campbell, 'Cultural Governance', p. 73; Debbie Lisle, 'The Surprising Detritus of Leisure: Encountering the Late Photography of War', Environment and Planning D: Society and Space, 29:5 (2011), pp. 873-90. 
the securitised. ${ }^{21}$ Roland Bleiker and Amy Kay (2007) have identified 'dialogical images' that challenge 'the iconic images of humanist [HIV/AIDS] photography, where the flow of information is controlled, hierarchical, and works in only one direction'. ${ }^{22}$ Klaus Dodds holds that the editorial cartoons by Steve Bell for The Guardian 'subvert the contemporary geopolitical condition'. ${ }^{23}$ This concern with the critical potential of images provides a clear point of convergence with studies from the fields of Political Communication, Art History, and Visual Studies that trace how icons become appropriated. However, as I will argue below the question of what a critical appropriation is, is complicated.

This article is aimed at an IR audience and as such one of its goals is to introduce existing work from outside of IR. That raises the question whether a specific IR approach to icons is warranted, or whether the reader may find the same arguments elsewhere? The answer, in short, is no. While providing an extremely valuable set of writings, works from Visual Studies, Communication, Art History, etc. have not theorised the international dimensions of iconic images. These international dimensions fall in three parts. First, some icons gain recognition and generate responses across state borders and this in turn open up the question of effect beyond that of domestic electoral politics which has been the traditional domain of Political Communication. Second, to theorise the icon as international is not only to conduct comparative studies of how domestic media in different countries cover foreign policy events - another stable of Political Communication research - but to ask how 'the international' itself becomes constituted as a particular space separate from 'the national'. Third, it is to theorise icons as inherently contested and always invoking national and international 'wes' [plural] which are fractured and thus not identical to a homogenous national citizenry or international community.

The article proceeds as follows. The first section provides a discussion of how to define the icon, an account of the emotive qualities of icons, and a conceptualisation of the international icon. The second section turns to a discussion of how icons can be said to have a political impact drawing in works on the CNN-effect, news coverage, and the contemporary media environment. The third section theorises the relationship between an icon and the images that are generated through its appropriation and presents a three tiered analytical strategy for studying the impact of the international icon on world politics. The fourth section applies the theoretical framework developed in the first three sections in a case study of 'The Hooded Man' photo from Abu Ghraib. The fifth and concluding section reflects on the wider potential for research on iconic images in IR.

\section{Introducing the international icon}

\section{Defining the icon}

The word 'icon' is used colloquially to refer to humans who achieve celebrity status, to logos such as Apple's trademark, to symbols like the swastika, as well as to easily

\footnotetext{
21 Möller, 'Photographic Interventions'; Vuori, 'A Timely Prophet?'.

22 Roland Bleiker and Amy Kay, 'Representing HIV/AIDS in Africa: Pluralist Photography and Local Empowerment', International Studies Quarterly, 51:1 (2007), pp. 139-63, 157.

23 Klaus Dodds, 'Steve Bell's Eye: Cartoons, Geopolitics and the Visualization of the "War on Terror", Security Dialogue, 38:2 (2007), pp. 157-77, 174.
} 
recognisable and widely disseminated images, mostly photographs that 'made history'. ${ }^{24}$ This article follows the majority of the academic literature in Visual Culture, Communication, and Art History and defines icons according to the last usage. ${ }^{25}$ This definition is arguably more narrow than the colloquial and some might find it too narrow on the grounds that some symbols are highly political (take the use of swastika in recent Greek protests against the financial conditions required by the EU), that logos can be appropriated in critical ways (MacDonald's Golden Arches), that 'iconic humans' might be drawn from the field of politics (Nelson Mandela) or that their celebrity status is used to campaign for political causes (Bono's role in the RED campaign to bring drugs to HIV/AIDS patients in Africa). Yet, this article is focused on freestanding, recognisable images on the grounds that they constitute a sufficiently distinct phenomenon with particular dynamics and implications for domestic and international politics, dynamics and implications that set them apart from logos, symbols, and iconic humans and celebrities. The article proceeds from Robert Hariman and John Louis Lucaites' definition of the icon (slightly modified) as 'those [photographic] images appearing in print, electronic, or digital media that are widely recognized and remembered, are understood to be representations of historically significant events, activate strong emotional identification or response, and are reproduced across a range of media, genres, or topics' ${ }^{26}$

As might be noticeable from the modification to Hariman and Lucaites' definition, they, like most existing studies, focus on photographic icons. Within the media of photography, photojournalism might be the genre from which most icons are drawn. The photos from Abu Ghraib are not photojournalistic however, but amateur photography not intended for a broader public use; the video from which the iconic still photograph of the dying Neda is drawn is now referred to as citizen journalism. ${ }^{27}$ Moving further away from photography's claim to record events factually there are images from other genres that satisfy the general part of Hariman and Lucaites' definition as images from the genres of drawing, painting, and printmaking have achieved iconic status. The genre of political cartooning has a history of producing domestic and international crisis of which the Muhammad Cartoon Crisis of 20056 is a recent example. ${ }^{28}$ Political posters have a tradition of seeking to rally a population around an ideological, patriotic, or revolutionary cause, usually incorporating imagery and slogans. J. M. Flagg's 1917 'I want you for U. S. Army' is a classical case in point; more recently Shepard Fairey's 'Hope' poster of Barack Obama has been lauded as 'iconic' of the 2008 presidential election and has provided the template for commemoration of 'Neda' in 2009, for Occupy Wall Street with a Guy Fawkes replacing Obama, and in support for Edward Snowden. ${ }^{29}$ The concealment of Picasso's Guernica at the entrance to the UN Security Council as Sectary of State

24 Brink, 'Secular Icons', p. 137.

25 For studies that adopt a wider conceptualisation of icons, see Alexander et al., Iconic Power.

26 Hariman and Lucaites, No Caption, p. 27.

27 Mortensen, 'When Citizen Photojournalism'.

28 Art Spiegelman, 'Drawing Blood: Outrageous Cartoons and the Art of Outrage', Harper's Magazine, 1873 (2006), pp. 43-52; Constance C. McPhee and Nadine M. Orenstein, Infinite Jest: Caricature and Satire from Leonardo to Levine (New Haven: Yale University Press, 2011); Lene Hansen, 'Theorizing the Image for Security Studies: Visual Securitization and the Muhammad Cartoon Crisis', European Journal of International Relations, 17:1 (2011), pp. 51-74.

29 David Craven, 'Present Indicative Politics and Future Perfect Positions: Barack Obama and Third Text', Third Text, 23:5 (2009), pp. 643-8, 644; Mortensen, 'When Citizen Photojournalism', p. 7. 
Colin Powell and American UN Ambassador John Negroponte presented 'evidence' of Iraqi weapons of mass destruction in February 2003 and the subsequent adoption of the painting in antiwar protests illustrate that artworks can achieve iconic status, too. ${ }^{30}$ As our definition of icons should be open to images from any visual genre, we should simultaneously acknowledge that those vary in terms of their epistemic conventions and the way in which audiences are expected to respond.

A final definitional distinction is between the discrete and the generic icon. The former refers to 'a single image with a definitive set of elements - the famous photo or footage [or other image]', the latter to when 'certain elements are repeated over and over, from image to image, so that despite varying subjects, times, and locations, the basic scene becomes a familiar staple, a visual cliché'. ${ }^{31}$ Discrete icons may actually consist of several images as in the case of 'Tiananmen Square' where three images circulate but 'nobody seems to care enough about the differences to comment on them'. ${ }^{32}$ This article is primarily concerned with the discrete icon on the grounds that there are specific dynamics surrounding it: it has a distinctiveness and an identity, a specific story about its gestation and circulation, and a 'nodal point' character. Yet, the category of generic icons is important, first, because there are cases of images that comply with our general definition even if one particular image cannot be picked out as 'the' iconic one. Lynching photographs from the American South for example arguably had and have such a status. Paintings of the Virgin Mother and Child in Western art are another example. ${ }^{33}$ Second, the concept of the generic icon is methodologically useful for identifying and understanding the iconic status of discrete icons because the latter may gain some of their visual power from referring to previous icons and these are often of a generic kind. ${ }^{34}$ Mette Mortensen describes this as an 'icon's iconicity', ${ }^{35}$ or we might use Julia Kristeva's theory of intertextuality to coin the concept of inter-iconicity. Inter-iconicity refers to the way in which an icon supports its claim to iconic status through referencing older icons. Importantly, through this process of 'icon quoting', the iconic status of the older image is also reproduced. One might for example read the image of charred contractors hanging from the bridge of Fallujah in 2004 as invoking the photos of dead American soldiers being dragged through the streets of Mogadishu in 1993, an inter-iconicity supported by media coverage such as San Francisco Chronicle's front page story on 1 April 2004: 'Horror at Fallujah: In U.S., echoes of Mogadishu'. Finally, generic icons might be closer to the original Christian understanding of the icon where no specific image was 'the' icon, icons were rather a special category of divine images, an understanding to which we now turn.

\section{Religious and photographic icons}

An exploration of the iconic image might usefully begin with the word's etymological roots, the Greek eikon 'simply means picture, image in the broadest sense'. ${ }^{36}$ From

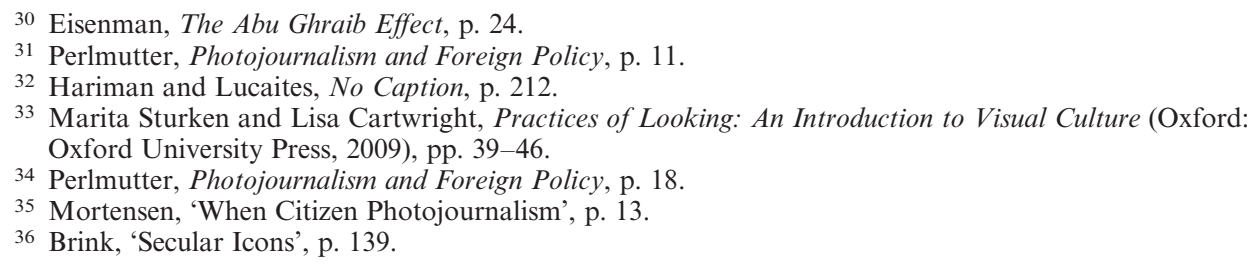


the ancient Greek world, the word travelled to the early Christians and the Eastern Orthodox Church where icons were cult images 'which according to legend were not created by human hands, [and] were regarded as authentic copies of the "original images" of Christ, the Virgin Mary, the saints or biblical scenes' ${ }^{37}$ Crucially, argues Cornelia Brink, 'There seemed to be a direct causal relationship between the copy and the original image', such that through the icon the 'invisible divine' could be imagined by the believing spectator. ${ }^{38}$

As noted above, most contemporary academic work theorise iconic images as photographs. The photograph obviously provides a different kind of documentation than the Orthodox icon, namely one based on the exact reproduction of events in the physical world, yet what unites the two kinds of icons is that both are believed to be authentic copies of what took place or existed. ${ }^{39}$ Where the religious icon provides a conduit to the realm of the divine, the photograph recreates the space and moment of its capture, that is, in Judith Butler's words 'a kind of promise that the event will continue' ${ }^{40}$ Both forms of icons thus stand in an emotionally charged relation with its spectator or devotee. The emotional quality bestowed upon icons is stressed in Hariman and Lucaites' definition listed above. It is also brought out by visual theorist Hans Belting who describes how we might look at images 'as if we were exchanging glances with living humans', although of course images 'cannot "glance" by themselves'. ${ }^{41}$ Adopting the distinction between depth and surface, Jeffrey C. Alexander suggests that icons uses the latter to draw us deeper, 'the icon points outside of itself, and outside of the subject, to something else, something in the world'. ${ }^{42}$ These theorisations of the icon's emotive, captive qualities effectively define the icon according to its impact on the viewer. Importantly, the capacity to evoke 'iconic emotionality' cannot be derived exclusively from the image itself. First, images might be aesthetically beautiful and striking, yet not become icons. Nor are aesthetic qualities necessarily crucial as the example of Kurt Westergaard's sketch of Muhammad with a bomb in his turban - the icon of the Danish Cartoon Crisis - shows. Second, some depictions of suffering and agony become iconic, most others do not. Third, formal compositional traditions and aesthetic conventions identify socially embedded and thus powerful expectations about the form of knowledge produced through an image and about the expected audience response. ${ }^{43}$ Thus formal characteristics of a photographic image can in some cases provide a partial explanation why a particular image achieves iconic status when several images of the same event compete for iconic candidacy. ${ }^{44}$ Perlmutter holds more specifically that 'One formal element that most icons seem to share, however, is their spareness', yet some icons, like 'Napalm Girl' involve quite a complex composition. ${ }^{45}$ To say that no image is destined to become iconic solely by virtue of its composition or the significance of the event(s) it depicts is

37 Ibid., p. 139.

38 Ibid., p. 139.

39 Ibid.

40 Judith Butler, 'Torture and the Ethics of Photography', Environment and Planning D: Society and Space, 25:6 (2007), pp. 951-66, 959.

41 Hans Belting, 'Body and Image', in Jeffrey C. Alexander, Dominik Bartmanski, and Bernhard Giesen (eds), Iconic Power: Materiality and Meaning in Social Life (New York: Palgrave Macmillan, 2012), pp. 187-202.

42 Jeffrey C. Alexander, 'Iconic Experience in Art and Life: Surface/Depth Beginning with Giacometti's Standing Woman', Theory, Culture \& Society, 25:5 (2008), pp. 1-19, 7.

43 Lisle, 'The Surprising Detritus'.

44 Perlmutter, Photojournalism and Foreign Policy, pp. 18-20.

45 Ibid., p. 18. 
to argue that there have to be agents - editors, journalists, politicians, commentators who constitute the image as having iconic power. According to Perlmutter this typically happens immediately upon publication, yet as the Cartoon Crisis shows, it might also take months of discursive construction to generate and convince an audience that an image has an exceptional status. ${ }^{46}$

Another similarity between religious and photographic icons is that both achieve a symbolic status, that is, they 'claim to condense complex phenomena and represent history in exemplary form' ${ }^{47}$ Wars, for example, become memorialised through a set of iconic photographs that symbolise a much larger body of carnage, destruction, and glory; ${ }^{48}$ the Virgin Mary embodies a religious universe. Icons thus become like visual nodal points, that is key signs within discourses that construct say 'Iwo Jima' as emblematic of American patriotism, virtue, sacrifice, and solidarity. Hariman and Lucaites argue that iconic images are salient for public, political life as their status is deeply connected to - if not caused by - an ability to act as 'symbolic resources for both social cohesion and political dissent'. ${ }^{49}$ Icons might even 'reconstitute a public during a period of crisis or perennial conflict'. ${ }^{50}$ The epistemic-political status of the icon is, in other words, not just to document, but to actively animate a sense of community, identity, and purpose. The image, the political community and those constituting the meaning of images for the public thus enter into a productive relationship that establishes the meaning and authority of each: of what images mean, of who 'the public' is, and what it implies to speak with authority about images and the public good. One might ask whether Hariman and Lucaites' theory builds on too much of a commitment to, or preferences for, a liberal, or Habermasian, understanding of politics as deliberation and dialogue among equals and of political community as therefore ultimately always capable of unity and conciliation. ${ }^{51}$ Most of their cases show lines of tension in the American public, but it is nevertheless tensions that can be managed within an American community. The more poststructuralist position of this article is rather that icons are significant precisely because they are articulated in relations to a community or identity, which is inherently unstable. ${ }^{52}$

Regardless of whether icons are theorised as underscoring cohesion or fracture, the discussion above emphasises their widespread circulation, an audience's ability to recognise them and the emotional response they generate. Such images argue Hariman and Lucaites are far and few between. In the case of the United States, 'fifteen, twenty, maybe thirty at the most across a span of generations', ${ }^{53}$ and judged from Hariman and Lucaites' case studies it seems that iconic status requires at least a decade of republication. While this obviously ensures that the photographs in question can make a strong claim to being institutionalised, this leaves out 'instant icons': images that circulate immediately to a world wide audience generating an emotional

46 Ibid., p. 14.

47 Brink, 'Secular Icons', p. 141.

48 Perlmutter, Photojournalism and Foreign Policy, p. 17.

49 Hariman and Lucaites, No Caption, p. 39.

50 Ibid., p. 154.

51 Thomas Risse, “'Let's Argue!”: Communicative Action in World Politics', International Organization, 54:1 (2000), pp. 1-39.

52 David Campbell, Writing Security: United States Foreign Policy and the Politics of Identity (Manchester: Manchester University Press, 1992); Cynthia Weber, 'I am an American': Filming the Fear of Difference (Bristol: Intellect, 2011).

53 Hariman and Lucaites, No Caption, p. 6. 
response. ${ }^{54}$ Given the desire by many IR scholars to engage with international politics as it unfolds putting up a ten-year window would clearly be unfortunately. Opening up for images to become icons sooner also accommodates what Perlmutter identifies as a more fundamental shift in the 2000s such that 'in today's media, current history is being speeded up, at least in its photographic portrayals'. In response, he suggests that 'These new indelible images might be called the hypericons - they pass by fleetingly, gain attention, and then are replaced quickly by new icons. ${ }^{55}$ As the cases of Abu Ghraib or the falling World Trade Center shows, not all icons in the contemporary media environment are hypericons, as some do manage to institutionalise themselves past the ten-year window. Yet, a larger question is whether changes in media use, information technology, and political identity eventually lead to a different temporality of icon production and forgetting.

\section{Foreign policy, regional and global icons}

Moving from a general discussion of the icon to the question of the international icon the first question that arises is what 'the international' indeed means. One answer would be that international icons are simply those that comply with the definition of the icon on a global scale. What W. J. T. Mitchell calls 'world pictures' are thus 'globally circulated and instantly recognized icon[s], which requires only minimal cues, visual or verbal, to be called to mind' ${ }^{56}$ More concretely, I suggest a tripartite differentiation of the international icon into the categories of foreign policy icon, regional icon, and global icon based on how widely an image is circulated and recognised. 'Foreign policy icons' are a particular subset of domestic icons in that they depict foreign policy related events situated outside or within the territory of the state. Through their constitution of 'the foreign', and thereby the national Self, foreign policy icons bring 'the international' into domestic politics, but a foreign policy icon is not necessarily recognised outside of its particular national context. An example is images of ambushed soldiers that question a humanitarian operation but which do not reach audiences in other troop contributing countries. 'Regional icons' by comparison are recognised within more than one political community, but not globally. An example of a regional icon is the photo of Bosnian prisoners from 1992 that was widely circulated and emotionally responded to by news media, politicians and activists in Europe and North America. Global icons have, as the name suggests, a circulation beyond the regional. Examples of global icons are 'Tiananmen Square' from 1989, 'Napalm Girl', and the World Trace Center Towers on 11 September. This tripartite distinction acknowledges that the international system has had and has strong regional structures, ${ }^{57}$ and that some images might be crucial to foreign policy making at the regional level, but not at the global.

One weakness of this distinction is that the circulation of images is hard to quantify, and that it is even harder to measure the extent to which people recognise

\footnotetext{
54 Campbell, 'Atrocity, Memory', p. 1.

55 Perlmutter, 'Photojournalism', p. 119.

56 Mitchell, Cloning Terror, p. 142.

57 Barry Buzan and Ole Wæver, Regions and Powers: The Structure of International Security (Cambridge: Cambridge University Press, 2003).
} 
images, even within domestic contexts. ${ }^{58}$ Another critical question is whether the international media environment is now so transnationalised that a state-centred model is inadequate. Piers Robinson argues in a recent stock taking of work on the CNN-effect that new media technologies have facilitated the creation of a 'global political sphere', but that one should also be cognisant of how 'national, cultural and language barriers still keep most of the world's public attuned to their national media'. ${ }^{59}$ Steve Livingston, another author of key works on the CNN-effect and the international politics of media, holds more radically that developments in the realm of information technology (the internet, cell phones, and satellite uplinks) have lead to a 'scale shifting' such that 'state institutions will be bypassed altogether in networked flows of images, words, and other symbols' ${ }^{60}$ The blurring of the distinction between producers and consumers imply that traditional understandings of mass media as generating content and political elites as interpreting that content on the one hand and a passive, receiving audience on the other can no longer be sustained. ${ }^{61}$ In the case of 'Neda' for example images were sent from someone in Tehran to an Iranian asylum seeker in Holland who uploaded it to Facebook and YouTube from which it was immediately picked up by CNN thus entering mainstream news media. ${ }^{62}$ The online commemoration of Neda further illustrates that political communities may arise around iconic images across national boundaries.

The differentiation of the international icon into the categories of foreign policy icon, regional icon, and global icon is based on patterns of circulation and recognition. Yet, we might also approach the concept of the international icon in a different way, namely by asking how 'the international' is constituted through icons and discourses that assign them meaning. As R. B. J. Walker famously put it, the international is not a set of predefined actors or institutions, rather it is a space with a particular temporality, and it is constituted through a series of juxtapositions to the national. ${ }^{63}$ On the inside are politics, ethics, identity, and progress; on the outside are power, war, difference, and repetition. Yet, these dichotomies are not fully stable, and thus there is not a transhistorical, transcultural, universally shared notion of 'the international'. Thus we might ask how icons are situated within discourses that articulate 'the international' and how that 'international' constructs identity/difference, Self/Other, universality/particularity, progress/repetition, and reason/barbarism. Who and what, in more concrete words, appear as subjects, objects, actors, threats and opportunities, and with which identities and responsibilities? ${ }^{64}$ To illustrate, this approach to the international asks for example how the iconic image of the burning

58 Perlmutter describes the inability of his students to identify a series of presumably iconic photos. Perlmutter, Photojournalism and Foreign Policy, pp. 9-11. Such experiments provide valuable information about the capacity of potential audiences to recognise images as freestanding entities. Yet, the experimental design is also misleading insofar as 'icon viewers' never encounter images without some discursive contextualisation.

59 Piers Robinson, 'The CNN Effect Reconsidered: Mapping a Research Agenda For the Future', Media, War \& Conflict, 4:1 (2011), pp. 3-11, 9.

60 Steven Livingston, 'The CCN Effect Reconsidered (Again): Problematizing ICT and Global Governance in the CNN Effect Research Agenda', Media, War \& Conflict, 4:1 (2011), pp. 20-36, 28.

61 Ibid., p. 29.

62 Mortensen, 'When Citizen Journalism', p. 7.

63 R. B. J. Walker, Inside/outside: International Relations as Political Theory (Cambridge: Cambridge University Press, 1993).

64 Lene Hansen, Security as Practice: Discourse Analysis and the Bosnian War (London: Routledge, 2006). 
World Trade Center Towers on 11 September was constituted in terms of who were under attack, who the enemy was, what time the attacker was situated within, and thus whether war or dialogue should be adopted in response.

\section{The impact icons make: text, image, policy}

The discussion above has been based on the premise that icons have political significance; the Introduction pointed for example to the impact of the Abu Ghraib photos on American politics and international relations. Taking a closer look at how icons matter politically, how should we theorise the 'icon effect'? First, we need to clarify our assumptions about the image itself. This article proceeds from the assumption that an image does not provide a foreign policy utterance independently of texts (media, political elites, and others) that ascribe it meaning. ${ }^{65}$ By representing atrocities, violence, and death an image might present itself as a claim that something 'be done', but what that 'doing' is cannot be deduced from within the image itself. Icons are images that through their widespread circulation function as visual nodal points, they provide a partial fixation within an inherently unstable system of signs. ${ }^{66}$ Yet, even icons do not 'speak' foreign policy in the absence of textual discourse. As a consequence, they rely upon text and media for their production and circulation, whether old (newspaper, television, magazines) or new (websites, blogs).

Looking to the literature on icons, media coverage, and foreign policy we find an array of views of what 'impact' means. Often these views are implicit rather than explicitly argued and unpacking them is crucial to our understanding of why assessments of icons differ, but also for a wider understanding of how different approaches understand the politics of the icon. One approach to the icon asks whether images, particularly as relayed by news media change foreign policy. This is the general question of the CNN-effect literature, which Robinson recently concluded has found 'little evidence to date of a media-driven policy U-turn whereby news media coverage has forced unified officials to alter course'. ${ }^{67}$ Work on the CNN-effect has established, more specifically, that two factors determine the possibility of news media to influence the course of policy: the level of political elite-consensus and where an issue falls in terms of high-low politics. ${ }^{68}$ The higher the level of elite-consensus and the more high politics an issue is, the less is the impact of the news media. Given that many international icons relate to instances of war or international crisis, that is, traditional high politics, and that war is often characterised by elite-consensus this apparently leaves little room for media, and hence icons, to impact policy. Political Communication scholars working in this tradition have however expanded the scope of the 'icon impact' question asking whether icons influence public opinion on questions of foreign policy and if so if there is an effect on electoral politics. Perlmutter's seminal

65 Works in IR have taken different positions on this issue. Axel Heck and Gabi Schlag for example draw on German art historians Erwin Panofsky and Horst Bredekamp holding that iconic images may succeed in functioning as security acts independently of text due to their symbolic form. Frank Möller by contrast builds on social and visual theorist, W. J. T. Mitchell arguing that the image is inherently ambiguous lending itself to multiple interpretations and thus always in need of textual discourse. Heck and Schlag, 'Securitizing Images'; Möller, 'Photographic Interventions'.

66 Laclau and Mouffe, Hegemony \& Socialist Strategy.

67 Robinson, 'The CNN Effect', p. 6.

68 Ibid., pp. 6-7. 
study of the execution at the 1968 Tet offensive, Tiananmen Square in 1989, and Somalia 1993 found for example that only in the latter case - which brought images of dead Americans to the American public - was there a discernable impact on public opinion. ${ }^{69}$

Yet there are other ways to frame the question how icons impact international politics than whether icons cause a foreign policy shift or whether politicians are punished or rewarded for how they respond to icons. First, even in the case of 'instant' icons their effect on policy might not occur within the relatively short timeframe adopted by studies in the news events tradition. Rather, icons might 'influence public debate in a more indirect and long-term fashion'. ${ }^{70}$ The temporality of the news event tradition is in other words one of immediate impact, yet, what characterises iconic images is their ability to remain in circulation and be emotionally responded to over a longer period of time. 'Napalm Girl' for example continues to resurface both in its original form and as a template for editorial cartoons and artwork. As such it is a politically significant 'sign' in the visual discursive field even though a direct impact on foreign policy is hard if not impossible to quantify. Second, the fact that political elites might be successful in terms of articulating discourses that accommodate icons does not make the study of icons superfluous. Quite the contrary perhaps as one could argue that understanding such 'elite disciplining' of challenging icons is warranted from a normative, democratic perspective. Third, from the perspective of IR the question is not only what determines foreign policy within a domestic setting, or if public opinion is moved by iconic images, but whether images can create, deepen or solve international conflict. This implies a research agenda which includes studies of how state leadership, diplomats, and foreign policy civil servants seek to handle icons - in particular those that generate image crises - in public as well as through diplomatic channels. ${ }^{71}$

\section{Appropriations: the image as intervention}

Much work in the fields of Visual Culture, Art History, and Communication have discussed the image's ability to 'help build or reinforce a moral position', ${ }^{72}$ not least whether photography can bring atrocities to light in a manner which activates a public response while at the same time not be presenting those suffering as passive victims devoid of agency and dignity. ${ }^{73}$ Judith Butler argued with reference to the move of the Abu Ghraib photos from the news media to the gallery space that this did not simply reproduce the images in question, but 'gave rise to a different gaze'. This in turn implies that the image 'can be instrumentalized in radically different directions, depending on how it is discursively framed, and through what media presentation the matter of its reality is presented'. ${ }^{74}$ Scholars in Media Studies and

\footnotetext{
69 Perlmutter, Photojournalism and Foreign Policy.

70 Bennett et al., 'None Dare Call It', p. 481.

71 Rebecca Adler-Nissen, 'Diplomacy as Impression Management: Strategic Face-Work and Post-Colonial Embarrassment', Centre for International Peace and Security Studies, Université de Montreal McGill University, Working Paper, no. 38 (2012).

72 Campbell, 'Cultural Governance', p. 72.

73 Ibid.; Bleiker and Kay, 'Representing HIV/AIDS'.

74 Butler, 'Torture and the Ethics', p. 964, see also W. J. T. Mitchell, What Do Pictures Want? The Lives and Loves of Images (Chicago: University of Chicago Press, 2005), p. 142.
} 
Art History have made particular note of how appropriations - that is, images that work from an existing image to create new ones - can be of 'critical use', bring out an image's 'inherent subversive force', and act as 'sites of protest and opposition'. ${ }^{75}$

It is in part through appropriation that an iconic image remains in circulation and that its status as part of a collective visual memory is reproduced. ${ }^{76}$ Theoretically, the icon and 'its' appropriations are simultaneously different images and the same: different images because there is not a complete identity between the two and audiences unfamiliar with the icon will be unable to note the similitude; the same because appropriations draw upon the icon. One form of appropriation is where the icon is copied, but where new objects are added or parts of the old image are scratched out. Photographic icons are often appropriated this way, especially as digital technology has made it easier to alter an image. Another form of appropriation adopts the image as a clearly identifiable scene, such as in editorial cartoons using 'Iwo Jima'77 or 'Napalm Girl'. ${ }^{78}$ Appropriations might also copy parts of an image and incorporate those into new settings. A recent case is the "pepper spray cop' who 'pacified' protesters on the campus of UC Davis in November 2011 and who was inserted into famous paintings and photographs which were uploaded to the internet. ${ }^{79}$ Appropriations may stay with the media of the icon or remediate it by moving it to a new one. ${ }^{80}$

The critical potential of appropriations might stem from the latter's ability to bring out something that is located within the iconic image. Dorothea Lange's 'Migrant Mother' from The Great Depression is for example used as 'a stock resource for both advocacy on behalf of the dispossessed and affirmation of the society capable of meeting those needs' ${ }^{81}$ A critical potential can also reside in the possibility of turning an image against itself, or 'undoing' it, what Guy Debord called detournement. ${ }^{82}$ Although the critical capacity of appropriations is more frequently pointed to, it should be stressed that appropriations can also be conservative as when right-wing blogs transformed Fairey's Obama 'Hope' poster into an image of Lenin with the text ' 1917 ', 83 or be ambiguous in terms of their critical-conservative stance.

An appropriation can thus be theorised as an intervention in a double sense: into the icon itself and into the discursive field of which the appropriation becomes a part. Theoretically and methodologically, three guidelines for studying appropriations can be suggested. First, like in the case of icons and images in general, the meaning of an appropriation is constituted through textual discourses and intervisual references to previous images. As such we need to read appropriations through the text that accompanies them, that is text on/with the appropriation itself as well as the discourses that may assign meaning to the appropriation. Second, the question whether an appropriation makes a critical intervention needs to be similarly contextualised. What is 'critical' is itself frequently a topic of debate and we should therefore, when

75 Campbell, 'Cultural Governance'; Andén-Papadopoulos, 'The Abu Ghraib Torture', pp. 16, 20, 23.

76 Brink, 'Secular Icons', p. 135; Hariman and Lucaites, No Caption, p. 203.

77 Janis L. Edwards and Carol K. Winkler, 'Representative Form and the Visual Ideograph: The Iwo Jima Image in Editorial Cartoons', Quarterly Journal of Speech, 83:3 (1997), pp. 289-310.

78 Hariman and Lucaites, No Caption, pp. 171-207.

79 Katharine Q. Seelye, 'Pepper Spray's Fallout, From Crowd Control to Mocking Images', The New York Time (22 November 2011).

80 Weber, 'Popular Visual', p. 139.

81 Hariman and Lucaites, No Caption, p. 67.

82 Apel, 'Torture Culture'.

83 Mitchell, Cloning Terror, p. 10. 
possible, examine how appropriations are being read as 'critical' or not. Third, we should consider the limits of appropriation, that is, whether there are instances where appropriations have been censored and disappear from public view, and whether there are media, genre, and institutional locations where we would expect appropriation but where none have been made.

Based on the theorisation of the international icon above, I propose a three-tiered analytical and methodological strategy which for each step examines the following questions.

- Step 1: The iconic image itself

- What is the formal composition of the image and what do we actually see?

○ What 'factual' meaning is attributed to the image?

- What inter-iconicity is evident or attributed to the image?

o When multiple images exist, what might explain this image's rise to iconic status?

- Step 2: The international status and political impact of the icon

○ In terms of circulation is the icon a foreign policy, a regional, or a global icon?

○ How is 'the international' constituted through the icon and discourses attributing meaning to it?

- What political impact has the icon made and according to which criteria?

- Step 3: Appropriations of the icon

○ What is the range of appropriations in terms of media and geographical location?

○ Which appropriations are singled out as making critical interventions and why?

O Which alternative readings of 'the critical' might be possible?

○ Are there discernable limits to appropriation?

\section{An application of the international icon framework: 'The Hooded Man' from Abu Ghraib}

The last part of the article illustrates the theoretical framework presented above through a case study of 'The Hooded Man' from the Abu Ghraib files. This image is widely recognised as a global icon in terms of its circulation, it has generated numerous appropriations across a range of media and genres, and there is a substantial literature analysing the photograph, its appropriation, and the political impact it has had. Given space constraints, the analysis will not provide a detailed study of the circulation of 'The Hooded Man' or the general debates on the War on Terror or Abu Ghraib, but rather focus on the image's composition and inter-iconicity (in Step 1), its political impact and the way in which it has constituted 'the international' exemplified by the immediate response from the George W. Bush Administration (in Step 2), and whether appropriations have made a 'critical intervention' (in Step 3).

\section{Step 1: The iconic image}

That it was the image of the hooded prisoner that became the globally recognised icon of Abu Ghraib is perhaps surprising (see Figure 1; reproduced in colour in the 


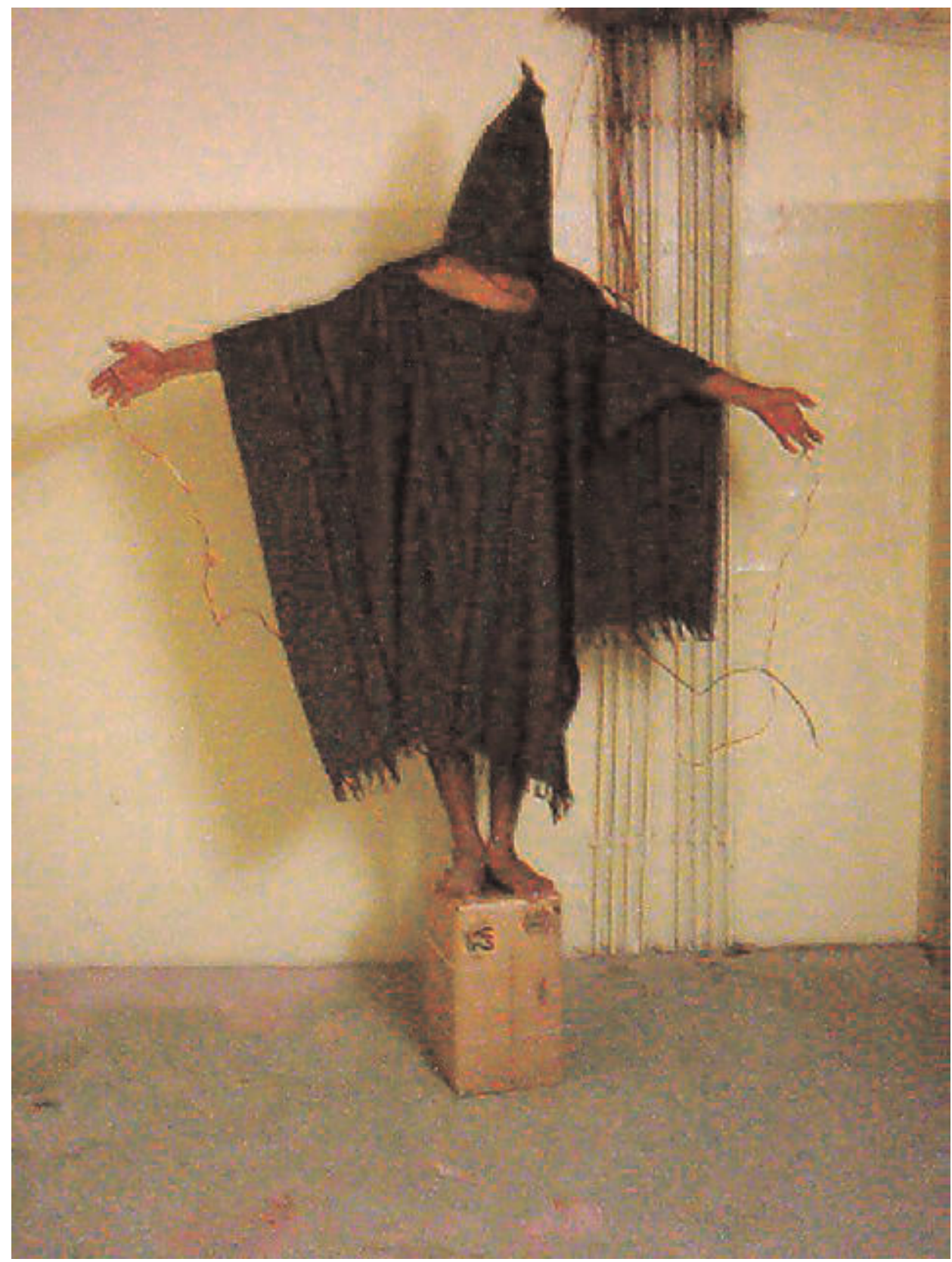

Figure 1. The iconic photo of 'The Hooded Man', Abu Ghraib 2003. (C) POLFOTO/AP

online version of this article). It is devoid of the nakedness and physical confrontation between prisoners and guards that characterise most of the other Abu Ghraib photos, thus its iconic status cannot be explained by this being the most bodily abusive image. The ability of the photo to embody 'Abu Ghraib' is thus related to its formal 
composition as well as its inter-iconicity. This photo has a 'striking simplicity at the level of form', 84 and a 'symmetry and contrastive color scheme', which in itself might make it aesthetically appealing. ${ }^{85}$ Mitchell argues that the hood 'renders the figure even more abstract and anonymous' and that the absence of a face reinforces the formal simplicity of the composition. ${ }^{86}$ The image's simplicity has also heightened its potential for appropriation as the freestanding, anonymous, clothed figure with its easily recognisable pose could be transposed into other images and settings. By comparison, another frequently printed photo of Lynndie England with a naked prisoner on a leash entailed a more elaborate scenery. Compared to the other Abu Ghraib images, 'The Hooded Man' is according to Mitchell 'like a Rorschach inkblot, inviting projection and multiplicity of association'. ${ }^{87}$ The absence of nakedness - and the anonymity of the man depicted - might also have made this a more publishable photo, especially in the United States. ${ }^{88}$

At the level of inter-iconicity, 'The Hooded Man' referred not to one specific image but to several generic icons. Two sets of past icons in particular have been suggested: of lynching in the American South and the suffering crucified Jesus Christ. ${ }^{89}$ Both situate 'The Hooded Man' within a history of victimhood and sacrifice, although the hood itself might also be seen as referencing the clansman. Stephen F. Eisenman argues further that the Abu Ghraib photos should be seen in the context of a long tradition in classical European and Western art which 'extends back more than 2,500 years, at least to the age of Athens', where the motif is 'tortured people and tormented animals who appear to sanction their own abuse'. ${ }^{90}$ Other has argued that ' $[\mathrm{t}]$ he serenity of the man on the box, with his outspread gesture of humble sacrifice, appeals to our sympathy and insight', thus modifying Eisenman's view that the prisoner is put in the position of condoning his own fate. ${ }^{91}$ Which specific inter-iconicity is invoked is thus subject to debate.

The final question at Step 1 is which factual meaning is attributed to the image and what we actually see. This might seem a banal question, but it nevertheless illustrates how 'facts' are attributed to images by discourses. First, 'The Hooded Man' is usually discussed as 'an' image, while there are in fact probably at least five photographs taken from several angles. ${ }^{92}$ These differ, some only slightly in terms of the angle of the arms while others show him in profile or carrying the cardboard box on which he stands out of the room..$^{93}$ The latter photo in particular is breaking with the

${ }^{84}$ Mark Reinhardt, 'Picturing Violence: Aesthetics and the Anxiety of Critique', in Mark Reinhardt, Holly Edwards, and Erina Duganne (eds), Beautiful Suffering: Photography and the Traffic in Pain (Chicago: University of Chicago Press, 2006), pp. 13-36, 16.

85 Mitchell, Cloning Terror, p. 147.

86 Ibid., pp. 147, 149.

87 Ibid., p. 149.

88 Butler, 'Torture and the Ethics'; Elizabeth Dauphinée, 'The Politics of the Body in Pain: Reading the Ethics of Imagery', Security Dialogue, 38:2 (2007), pp. 139-55.

89 Several commentators situated the Abu Ghraib photos within the genre of pornography and artistic mediations thereof. Eisenman, The Abu Ghraib Effect, pp. 30-41; Nicholas Mirzoeff, 'Invisible Empire: Visual Culture, Embodied Spectacle, and Abu Ghraib', Radical History Review, 95 (2006), pp. 21-44; Carrabine, 'Images of Torture'. The clothed nature of the hooded prisoner made this less relevant for this particular image.

90 Eisenman, The Abu Ghraib Effect, p. 16.

91 Andén-Papadopoulos, 'The Abu Ghraib Torture', p. 16.

92 Mitchell, Cloning Terror, p. 141.

93 The profile shot is reprinted in ibid., p. 142, the cardboard carrying image in Eisenman, The Abu Ghraib Effect, p. 28. Oddly enough this image is not discussed by Eisenman or printed elsewhere in the academic Abu Ghraib literature I have come across. 
serenity and potential Christian iconography of the iconic photo and the allusions to violence are less overt.

Second, judged from the image alone, one cannot in fact tell whether it is a prisoner or a guard under the hood. Nor does the image provide us with any clues as to its geographical location other than this is a place that is tiled in soft-tone colours. In terms of time, the cardboard box, wires, hood, and cloth only give us a vague contemporary reference. Although the prisoner is immediately referred to as 'him', the hooded and covered body provides no visible signs of gender (there were reports about female prisoners in Abu Ghraib, so this could have been the case) and while the man in the picture later testified that wires were attached to his toes and penis, ${ }^{94}$ these are not visible. As the identity of the man in the picture has subsequently been the topic of some controversy, what is significant is perhaps less the veracity of this claim, but how it has become a fact of the constitution of the meaning of "The Hooded Man' icon. Text needs in other words to inform us that this is from the Abu Ghraib prison, that this is a scene of abuse rather than for example rehearsing for a school play on the history of lynching in the Deep South, and that the prisoner is a man. To ask what we actually see in an iconic image and compare that to established accounts of 'what the image says' shows us in short the significance of discourse.

\section{Step 2: Circulation, the international and political impact}

The global circulation of 'The Hooded Man' is emphasised by numerous publications and debates over Abu Ghraib and the War on Terror still continue a decade after the photos were first made public. ${ }^{95}$ In the terminology developed above, this makes 'The Hooded Man' a global icon. As a consequence there are multiple 'local' - that is national and to some extent regional - debates and discourses that could be studied. Put differently, 'the international' is always constituted from a particular place and by specific discursive actors, even if - or perhaps especially when - those speaking and writing make the claim to be speaking on behalf of 'the' international community, humanity, or a similarly universal subject. In that sense, 'the international' is always an inherently unstable identity. With this as a theoretical startingpoint, how was 'the international' constituted by the government who was formally in charge of the Abu Ghraib prison, that is the George W. Bush Administration when 'The Hooded Man' became world news?96

Subsequent analysis has argued that the Abu Ghraib photos were largely absent from the American 2004 presidential election campaign and that the impact of 'Abu Ghraib' on American politics was limited. ${ }^{97}$ Yet, if we look to the first months after the photos became public the Bush Administration responded frequently and often in an emotionally charged register. As Secretary of Defense Donald Rumsfeld put it in

\footnotetext{
94 Apel, 'Torture Culture', p. 97.

95 See, for example, Carrabine, 'Images of Torture', pp. 19, 26.

96 The analysis below builds on academic works on Abu Ghraib and a close reading of 29 documents featuring interviews, public remarks, press conferences, and press briefings by President George W. Bush, Secretary of Defense Donald Rumsfeld, Vice President Richard B. Cheney, National Security Advisor Condoleezza Rice, and White House Press Secretary Scott McClellan between 30 April 2004 and 26 June 2004. Theoretically and methodologically, the analysis draws on discourse analysis as laid out in Hansen, Security as Practice.

97 Eisenman, The Abu Ghraib Effect, p. 8; Mirzoeff, 'Invisible Empire', p. 21.
} 
his testimony before The Senate and House Armed Services Committee 'the photos give these incidents a vividness - indeed a horror - in the eyes of the world', ${ }^{98}$ and President Bush's response was visceral: 'It makes me sick to my stomach to see that happen'. ${ }^{99}$ What is seen in the photos are 'horrible, horrible'100 and 'abhorrent' acts $^{101}$ and locating 'Abu Ghraib' on a scale of difference, Rumsfeld goes as far as describing this as 'the evil in our midst'. ${ }^{102}$ The constitution of 'Abu Ghraib' as a sickening product of abhorrent, evil practices is connected to this as an isolated incident carried out only by a few individuals. This is in turn makes 'Abu Ghraib' a 'catastrophe', something essentially incomprehensible and irrational, rather than a more widespread phenomenon or the product of institutional shortcomings. ${ }^{103}$ Thus, as the President repeatedly argued, this is 'not the way we do things in America'. ${ }^{104}$ Or, as National Security Advisor Condoleeza Rice put it, 'Americans do not do this to other people.' 105

The prison guards charged - and later convicted - were of course American in the formal sense of their citizenship, yet in terms of the constitution of 'the international' they were located by the George W. Bush Administration as outside of the American 'inside'. Having extradited those committing the 'horrible' acts at Abu Ghraib from 'America', 'the international' is populated by an American subject privileged vice a vice 'Iraq'. The hierarchical nature of the American-Iraqi relationship is evidenced by the certainty with which Rumsfeld stated that 'the truth is that the United States is a liberator, not a conqueror'. ${ }^{106}$ The US has, in short, not only the right, but the obligation to be in Iraq, and it - not 'Iraq' or 'Iraqis' - has the right to define the American presence as liberation. This effectively leaves little room for 'Iraqi' responses other than gratitude, a point underscored by Bush emphasising 'how decent and compassionate our troops are. I hear stories all the time of people working with orphans or people helping schools be formed or people working to provide medical care for people.'107 But not only should 'Iraqis' be grateful, they should be cognisant of the difference between American society and the Iraq they inhabited under Saddam Hussein, a difference proven by the fact that those responsible for 'Abu Ghraib' are being duly prosecuted. This, Bush explains, stands in stark contrast to how 'if there was torture under a dictator, we would never know the truth'. ${ }^{108}$ Thus, effectively, 'Abu Ghraib' becomes a testimony to the strengths of

98 Donald Rumsfeld, 'Statement of hon. Donald H. Rumsfeld, Secretary of Defense, May 7, 2004', S. HRG. 108-868 - Review of Department of Defense detention and interrogation operations, 7 May 2004; 11 May 2004; 19 May 2004; 22 July 2004; 9 September 2004 (Washington, DC: Government Printing Office), pp. 5-11, 11 .

99 George W. Bush, 'Interview With Al-Ahram International, May 6, 2004', Public Papers of the Presidents of the United States: George W. Bush (2004, Book I) (Washington, DC: Government Printing Office), pp. 791-9, 795.

100 Ibid., p. 795.

101 Bush, 'Interview With Alhurra', p. 767.

102 Rumsfeld, 'Statement', p. 11.

103 Ibid., p. 9.

104 George W. Bush, 'The President's News Conference With Prime Minister Paul Martin of Canada, April 30, 2004', Public Papers of the Presidents of the United States: George W. Bush (2004, Book I) (Washington, DC: Government Printing Office), pp. 690-3, 692.

105 'Dr. Condoleezza Rice Discusses Iraq and the Middle East', available at: \{http://www.presidency. ucsb.edu/ws/index.php?pid=80924\&st=Abu+Ghraib\&st1=image $\}$ accessed 9 July 2014.

106 Rumsfeld, 'Statement', p. 10.

107 George W. Bush, 'Interview With the American Forces Radio and Television Service, May 10, 2004', Public Papers of the Presidents of the United States: George W. Bush (2004, Book I) (Washington, DC: Government Printing Office), pp. 836-41, 837.

108 Bush, 'Interview With Al-Ahram', p. 795. 
'America', rather than its weaknesses, and the 'stain on our country's honor and our country's reputation' is to make only a temporary dent in the reputation of the United States. ${ }^{109}$ As a consequence of this construction there is no position from which opposition to American presence in Iraq can be legitimately argued. Nor is there a political subject in Iraq - a government or other collective representational actor - worthy of being consulted with or apologised to. ${ }^{110}$

The Bush Administration strove to construct a positive and unambiguous relationship between the Iraqi, the American, and the international community but its discourse was widely contested, especially outside the United States. 'The international' in turn became a contested and fractured space with relations of dominance and power where 'Abu Ghraib' itself was ambiguously located. 'Abu Ghraib' was Iraqi insofar as it became known to a global audience as a prison facility located within the state of Iraq. It was American insofar as those who were in control in the photos - or in some cases like 'The Hooded Man' outside the frame - represented the US Armed Forces. And it was international insofar as the photos were constituted as part of the War on Terror fought not only by the US, but by the Coalition of the Willing. The space of 'Abu Ghraib' was - and is - simultaneously Iraqi-Americaninternational, yet there is an undecidability at work in this relation: the space was not Iraqi as if it were, the prison would be run by Iraqi authorities, not Americans and the space was not American as this was beyond US territory and the subjects incarcerated non-American. What arise is in turn an ambiguous international space that is US-Western dominated, yet, where key actors from the Bush Administration seek to erase this dominance by constituting their presence as sanctioned by universal values and defence of the Iraqi people. Read through the classical IR dichotomies of inside/ outside, politics/power, and universality/particularity, the photos effectively 'internationalise' the American presence in Iraq and they demonstrate a space governed in a manner at odds with the liberal universalism claimed by the US government. ${ }^{111}$

\section{Step 3: Appropriations}

The debates over what 'Abu Ghraib' signified took place not only through texts and speeches, but through appropriations of 'The Hooded Man' covering the genres of magazine covers, murals, posters, painting and drawing, cartooning, and installation. ${ }^{112}$ In addition to being the central figure, he features more inconspicuously in backgrounds and off-centre ${ }^{113}$ or in appropriations of other iconic images such as 'Napalm Girl'. ${ }^{114}$ Appropriations identified and discussed in the academic literature

109 George W. Bush, 'The President's News Conference With King Abdullah II of Jordan, May 6, 2004', Public Papers of the Presidents of the United States: George W. Bush (2004, Book I) (Washington, DC: Government Printing Office), pp. 783-8, 787.

110 Bush does tell afflicted prisoners and their families how sorry he is, but this does not extend to the level of a collective Iraqi subject. Bush, 'Interview With Al-Ahram', p. 795.

111 Khalili, Time in the Shadows.

112 Apel, 'Torture Culture'; Eisenmann, The Abu Ghraib Effect; Andén-Papodopoulos, 'The Abu Ghraib Torture'; Carrabine, 'Images of Torture'.

113 See, for example, the hooded prisoner entering a 'CIA' plane in the background of Steve Bell's editorial cartoon, 'Come Fly With Me', for The Guardian (9 December 2005), reprinted in Dodds, 'Geopolitics', p. 172

114 Editorial cartoon, 'Abu Ghraib Nam' by Dennis Draughon, reprinted in Hariman and Lucaites, No Caption, p. 202. 
on Abu Ghraib are predominantly set within an American, European, or Middle Eastern context, but that might well be because scholars have devoted less attention to other parts of the world less directly involved in the war in Iraq.

In the attempt to pursue the question how appropriations might act as critical interventions in foreign policy debates, the analysis below is focused on two appropriations of 'The Hooded Man'. Both show that it might be difficult to provide a clear yes-no answer to the question of an image's critical potential, that is, that these images might be read in ways that underscore openness rather than certainty.

The first example is a 26 December 2005 cover of The Nation by Steve and Janna Brower (see Figure 2; reproduced in colour in the online version of this article). Published more than a year and a half after the photos from Abu Ghraib were released, 'Abu Ghraib' itself is not explicitly mentioned on the cover or in the opening Editorial. Yet, the hooded prisoner has come to embody the existence of a 'new torture complex - centred in the executive branch of the government but with tentacles throughout the country' including 'the military, the law, medicine, media, and the academy'. ${ }^{115}$

Steve and Janna Brower's cover makes a clearly identifiable reference to 'The Hooded Man', yet, there are also important compositional changes. We are now zoomed up much closer to the prisoner than in the original photo, and the perspective is one of looking up at the prisoner rather than straight at him. He is being forced up into a corner, the wires are barely visible, and his hands are still stretched out, but at a lower angle. The zooming in has taken us closer, but we are invited to come closer still, either to embrace the hooded prisoner or to see what our inaction is causing him. The striking red headline running across his torso provides a textual linkage between 'Abu Ghraib' and a wider 'Torture Complex'. In terms of the composition of the image, it accentuates the hood, which is draped such that a hole appears where the face presumably is located. Thus we are brought in to personally face the prisoner in a starker way than in the original photo.

Particularly for an American audience, the genealogy of the hood invokes the history of lynching whether the hood covers the victim or the executioner. Yet, the Browers' cover is not only a mediation of the Abu Ghraib icon through the iconicity of one of the most traumatic parts of American history. Another, specific intericonicity is constituted through the fact that the cover is itself an appropriation of a 1942 World War II poster by Ben Shahn entitled 'This is Nazi Brutality' (see Figure 3; reproduced in colour in the online version of this article). The intertextuality between the two posters implies that those brutalising prisoners at Abu Ghraib - and more broadly those involved in (at least parts of) the War on Terror - are constituted as akin to Hitler's regime. ${ }^{116}$ As David R. Conrad described it decades before Abu Ghraib, '[a] hooded handcuffed victim dominates the poster, with a ticker tape announcing the terrible events superimposed on this brave but doomed figure'. ${ }^{117}$ Yet, it is only because of the text that we know this man is doomed: compared to the open, outstretched hands of the hooded prisoner, retained in Browers' cover, Shahn's prisoner's pose is one of knotted, defiant palms. Set within the context of World War II propaganda, this pose opens up for multiple readings and identifications: the prisoner might be the exterminated citizens of Lidice or it might be the fate of all - including

115 See also Eisenman, The Abu Ghraib Effect, pp. 24-30.

116 Editorial, 'Conspiracy to Torture', The Nation, 281:22 (2005), pp. 3-5, 3.

117 David R. Conrad, 'Ben Shahn as Aesthetic Educator', Journal of Aesthetic Education, 15:2 (1981), pp. $73-82,77$. 


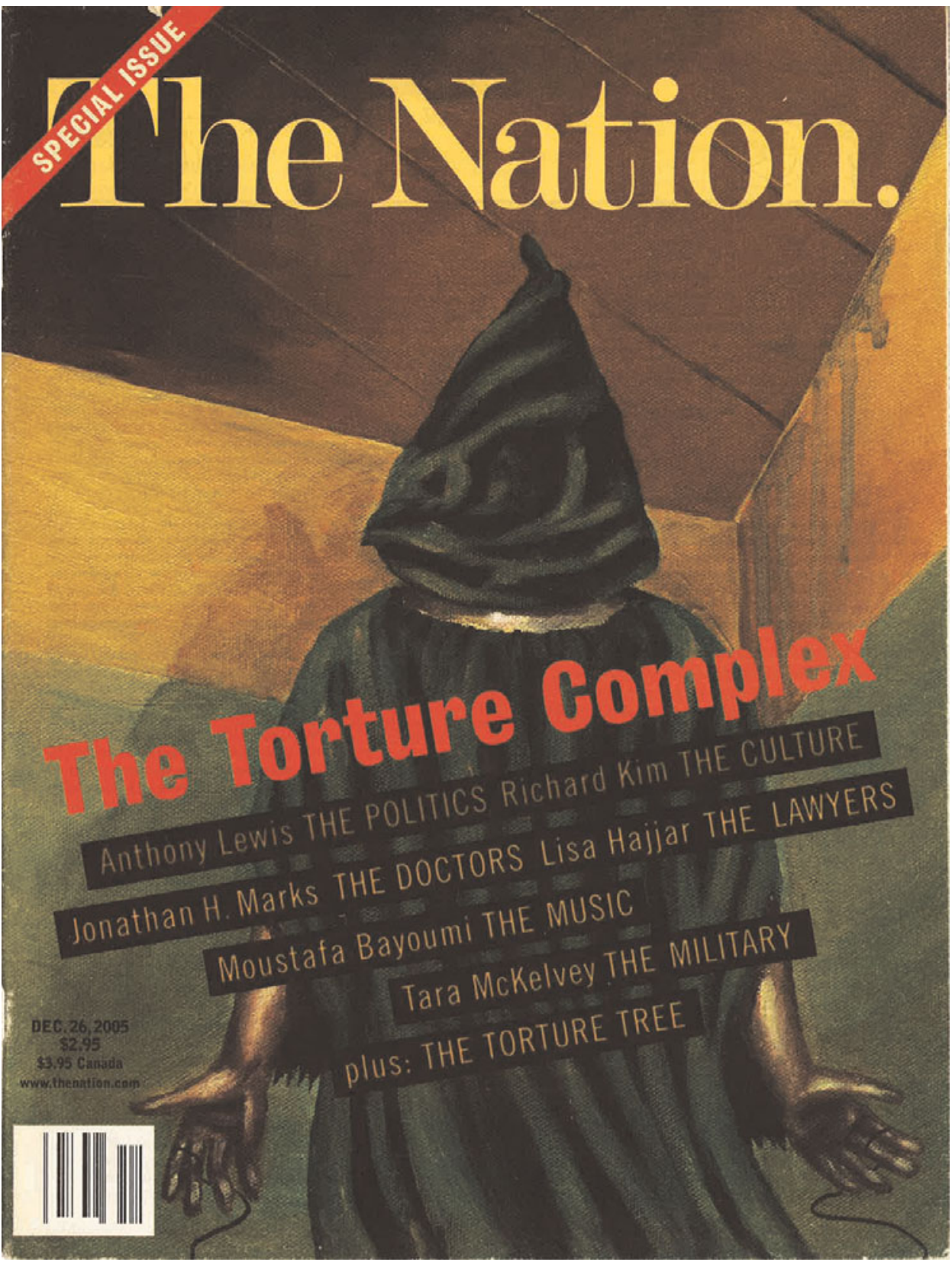

Figure 2. Steve and Janna Brower, cover of The Nation, 26 December 2005. Courtesy of The Nation.

Americans - if the war against Nazi Germany is not fully supported. The political discourse of the poster is thus not to succumb but to fight. Reading Brower's 2005 cover through the 1942 poster by Shahn provides the former with a higher degree of resistance as the latter encourages the former to clinch his fists. 


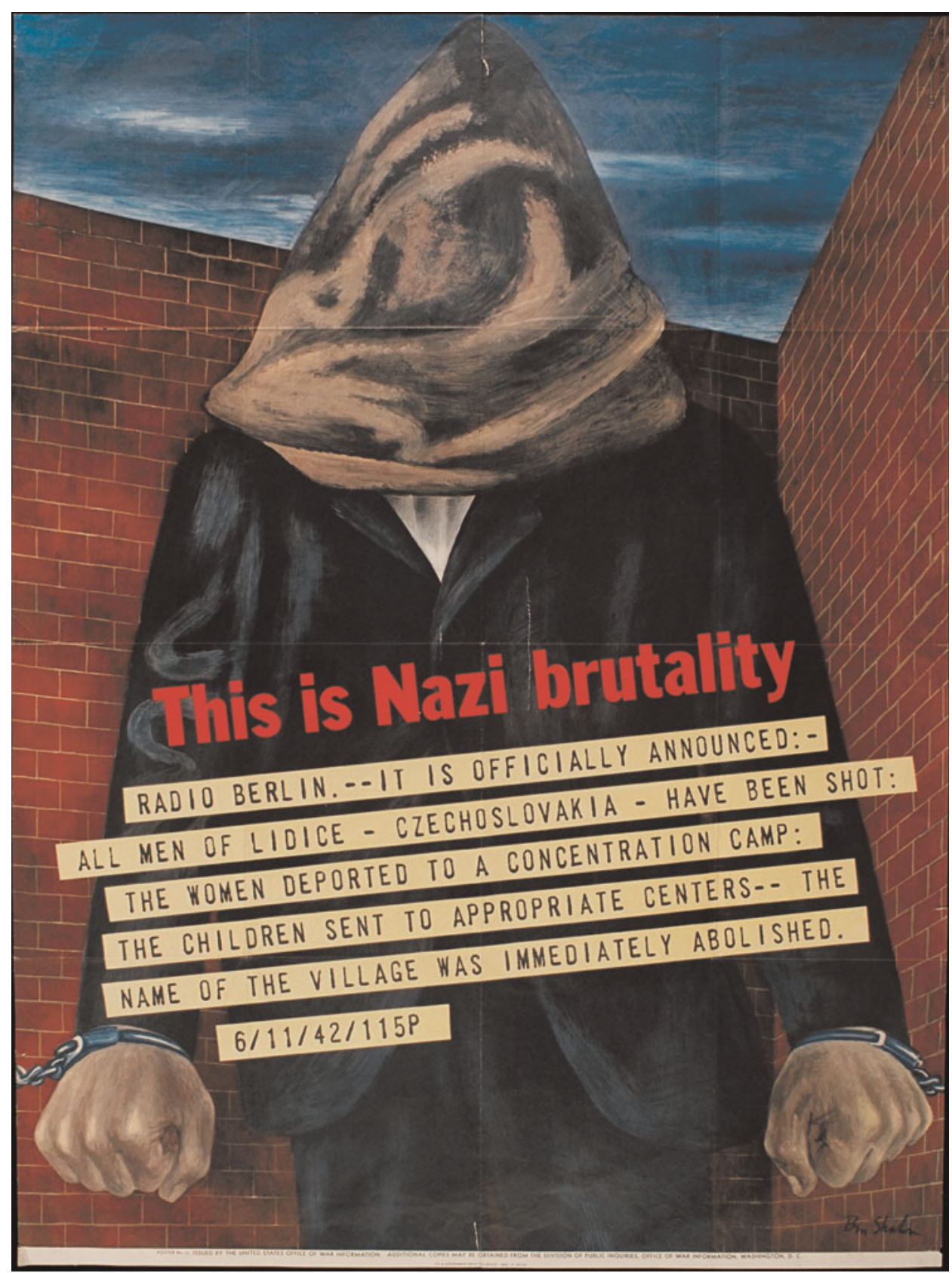

Figure 3. This is Nazi brutality, Ben Shahn, 1942. (C) Ben Shahn/billedkunst.dk 2014

The second example is a photograph by famed art photographer Andres Serrano featured on the 12 June 2005 cover of The New York Times Magazine (see Figure 4; reproduced in colour in the online version of this article). The composition of the cover allocates the hooded man centre stage, the cover story is featured in white font at the bottom of the page while four blocks of questions on the sides of the hooded man's 


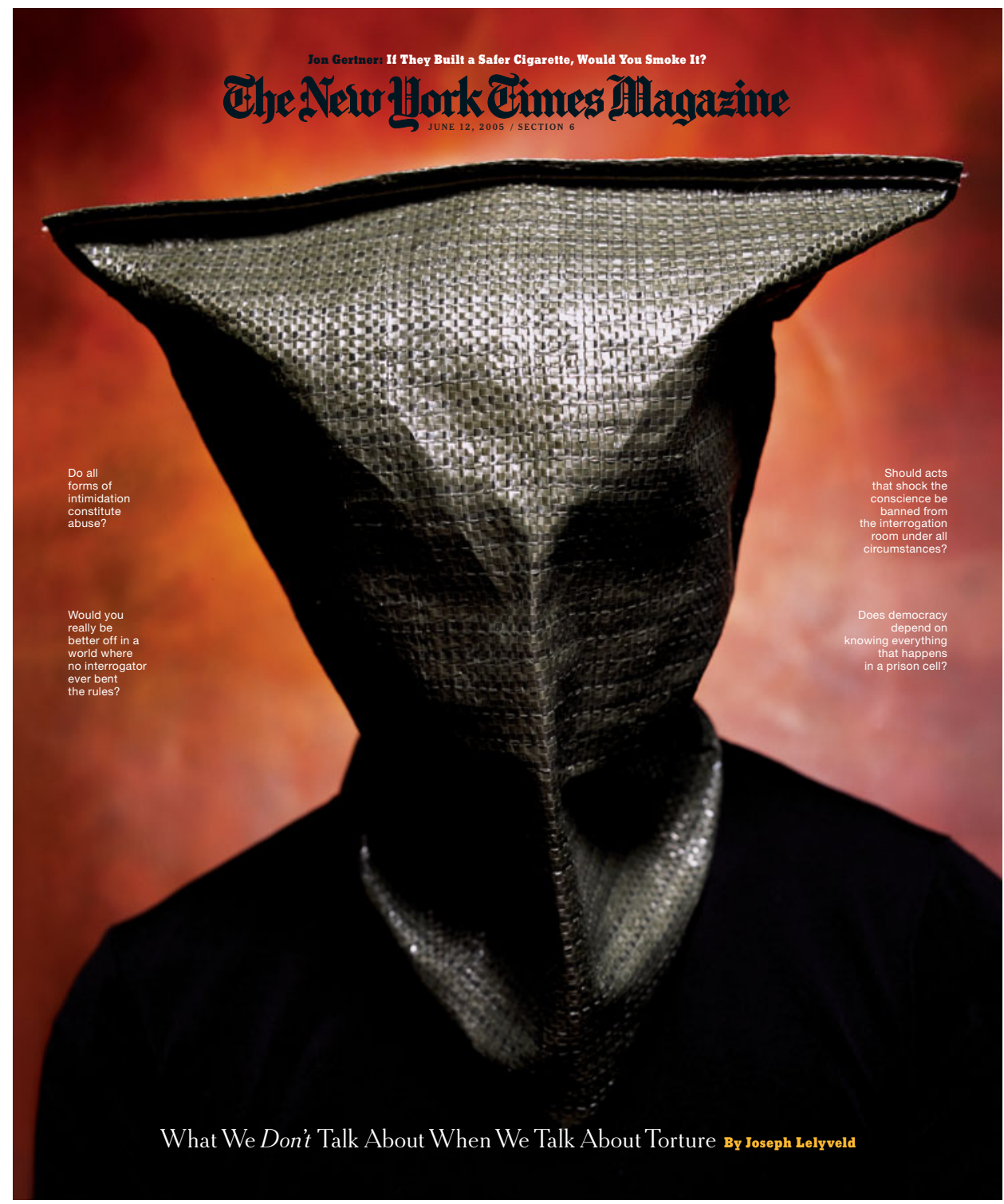

Figure 4. Andres Serrano/The New York Times Magazine, 12 June 2005 (2005 The New York Times. Used under License.

face are barely legible. When read, the questions all evolve around frequently raised issues concerning the use of torture, such as 'Would you really be better off in a world where no interrogator ever bent the rules?' In Erina Duganne's reading of the image 'the dramatic lighting; the intense, red-painted background; and the shallow depth of field lend the figure an ominous and dominating presence'. ${ }^{118}$ Duganne holds further

118 Erina Duganne, 'Photography After the Fact', in Mark Reinhardt, Holly Edwards, and Erina Duganne (eds), Beautiful Suffering: Photography and the Traffic in Pain (Chicago: University of Chicago Press, 2006), pp. 57-74, 71. 
that the use of words on the cover such as 'intimidation, interrogation, prison, and torture' means that it is 'unclear whether one should read the figure as the subject or the object of torture'. ${ }^{119}$ This ambiguity is, however, resolved as Duganne determines that the intervisual connections to Abu Ghraib 'encourage one to read the hooded figure as suffering and in pain', a reading, she argues, which is further supported by the essay within the magazine. ${ }^{120}$ Duganne's position is noteworthy because it illustrates the theoretical-ontological position that texts are superior to images: Serrano's image is disciplined by the words on the cover and by the essay located inside the magazine. It is also a reading which presumes that the appropriating image is inferior to the appropriated as Serrano's figure becomes one of suffering through its inter-visual reference to Abu Ghraib. These assumptions deprive the image of the potential to resist the textual discourses it is supposed to illustrate or validate, it also deprives new images of the capacity to unsettle previous ones by appropriating some of the formal characteristics and shifting others. The argument here is not that Duganne's reading of the cover is wrong, rather that it is only one among several plausible ones. Another such reading would be to see this less as an image of abjection than a menacing avenger and allow 'him' to resist the text surrounding him. ${ }^{121}$ Reading 'The Hooded Man' through Serrano's image, the former may thus be rallied to resist.

The hooded prisoner has been remarkably resilient in terms of not running into boundaries of appropriation. Perhaps the strongest concern would be that the image is so easily cut out, inserted and circulated that it, as Mitchell puts it, becomes reduced to 'an empty signifier or 'brand', like a corporate logo'. ${ }^{122}$ Ten years after its first publication, that does not however seem to have happened. Unlike Che's famous portrait, 'The Hooded Man' is not used to sell T-shirts, mouse pads, vodka, and a host of other consumer objects. ${ }^{123}$

\section{Conclusion}

This article has identified and introduced the international icon to the field of IR. International icons are freestanding images, widely circulated, emotionally responded to, and seen as representing significant historical events. They are found across a variety of genres, produced and reproduced by a range of media, and they are frequently appropriated and thus inserted into genres beyond the one in which they originated. The 'international' in international icons can be approached from two perspectives: at the level of circulation and recognition they come in the form of foreign policy icons, regional icons, and global icons; at the level of meaning production we should ask what 'international' spaces and subjects are constituted by those discourses that ascribe political significance to the icon. The article has argued that we should take a broad view of how icons matter to world politics rather than restrict it temporarily to the time immediately upon publication or spatially to domestic or

119 Ibid.

120 Ibid.

121 I wish to thank Laura Shepherd for the apt suggestion that the hooded figure might also be seen as vaguely alien.

122 Mitchell, Cloning Terror, p. 119.

123 Sturken and Cartwright, Practices of Looking, pp. 200-3. 
comparative politics. Moreover, we should consider the icon and its appropriation as interventions into foreign policy discourses while keeping the question of whether such interventions are critical open.

This article has illustrated the content and applicability of the international icon framework through the case of the hooded prisoner from Abu Ghraib. Thus, it is perhaps appropriate in conclusion to point out that this is not the only international icon that could be subjected to further study. Looking to the past decade, the following images mentioned above would for example qualify as either global or regional icons: Kurt Westergaard's drawing of the prophet Muhammad, the charred contractors from Fallujah, Shepard Fairey's 'Hope' poster of Barack Obama, and the video of Iranian activist 'Neda'. More recently, and from the category of generic rather than discreet icons we find the images of the victims of the chemical weapons attack in Syria in August 2013 or the photos of the more than 360 people who drowned off the coast of Lampedusa later that year. ${ }^{124}$ Yet, because iconic images continue to circulate through reproduction as well as appropriation, the study of international icons and their impact on world and domestic politics is never finished. 'Napalm Girl' for example is continuously republished in works dealing with the Vietnam War and its aftermath and it is appropriated in engagements with current events, for instance in political cartooning on the Abu Ghraib scandal. Thus, to return to 'The Hooded Man', we should expect to see him invoked as debate on the War on Terror and American foreign policy past the presidency of George W. Bush - and Barack Obama - continues. Given the iconic status of this image, it is also likely to be appropriated in commentary on events not directly related to the war in Iraq.

The international icon framework laid out in this article might also be subjected to further theoretical elaboration and possibly revision. First, the need for a research agenda on global icons is accentuated by the growth in new media technology and the ensuing transformation of who can produce and circulate images. Cell phone technology has for instance produced a genre of citizen journalism that was unheard of only two decades ago. The instantaneity of communication and the reach of audiences beyond one's own state of presence challenge IR scholars across all perspectives to rethink key concepts and assumption. Specifically, in terms of the international icon, this raises the question whether the distinction between 'national' and 'international' icons is itself in need of theoretical adjustments as media audiences and producers loosen their territorial anchoring. Another question is whether the speed of image production and circulation is now such that icons might more easily be produced, but that it might be harder for iconic images to establish themselves in the long term. Were that the case, our response should not be to abandon the concept of the icon, but rather to retheorise the role of temporality. Second, most examples discussed in this article have been either global or if regional involved the United States and/or Europe as one of the regions in which an image has achieved iconic status. This raise the question whether there are dynamics - in terms of media, politics, and circulation - outside of the West that call for a more nuanced theoretical framework than suggested here.

124 BBC News Europe, 'Lampedusa Boat tragedy: Migrants "Raped and Tortured"' (8 November, 2013), available at: \{http://www.bbc.com/news/world-europe-24866338?print=true $\}$ accessed 9 July 2014. 